\title{
Buddhist Nuns through the Eyes of Leading Early Tang Masters
}

(Ann Heirman, Ghent University)

The first Chinese Buddhist nuns were ordained in the monks' community only, despite disciplinary guidelines stating that nuns should be ordained both in the nuns' community (bhikṣuñisamgha) and in the monks' community (bhikṣusamgha). As can be seen from the Biqiuni zhuan 比丘尼傳, which is a collection of biographies of Chinese nuns compiled in the early sixth century, this situation gave rise to discussions on the legal status of the Chinese bhikṣun̄isamgha. In ca. 433, a so-called second ordination became possible with the arrival of a group of Sinhalese nuns who could legally act as nun witnesses, thus making it possible that for the first time in history, a dual ordination, in both communities, could be held in China. It confirmed the full status of Chinese nuns in monastic institutions. Nevertheless, the status of women still raised questions and even doubt, with male dominance remaining standard. This male standard is particularly underscored in the writings of influential vinaya (disciplinary) masters, such as Daoxuan 道宣 (596-667), Daoshi 道世 (?-683), and others. In this article, their views will be analyzed and compared, against the background of the nuns' institutional role.

\section{$\underline{\text { Keywords }}$}

Buddhist nuns, Chinese Buddhist monasticism, gender 


\section{Introduction}

When, in the fifth century, a so-called second ordination ceremony was held for Chinese Buddhist nuns, it confirmed the full status of nuns in monastic institutions. Over the same period, some quite inspiring women were active in several nunneries, as shown, for instance, in the Biqiuni zhuan 比丘尼傳 (T.2063), a collection of biographies of Chinese nuns compiled in the early sixth century. ${ }^{1}$ Nevertheless, the position of women still raised questions and even doubt, and influential Chinese vinaya (discipline) masters continued to portray Buddhist nuns in rather negative terms. It is on this portrayal, and on its specific features, that this article focuses. The masters of the (early) Tang dynasty (609-907), in particular, play an essential role in it, given their position as founding masters of a fully developed Chinese Buddhist institutional monasticism. This negative picture, however, is not the full story, and women certainly went beyond the limitations and literal interpretations of vinaya rules. ${ }^{2}$ Moreover, apart from the vinaya texts, other sources, such as biographies, miracle tales, archeological records, manuscripts, and memorials, testify to a female agency in medieval China, each bringing their own perspective. In recent times, these sources have been studied intensively and more is yet to come. These studies have shown a much more balanced picture of Buddhist women, and have brought to light several important roles taken up by Buddhist nuns. As a counterbalance to the opinions of the vinaya masters, these findings are good to bear in mind, as an essential background against which to contextualize the masters' sayings. Therefore, I will first give a short, and inevitably non-exhaustive, overview in order to disclose the context in which Buddhist women were living. In the main part of this article they will be shown as they have been defined, portrayed and delimited by the most influential Tang dynasty monastic masters.

In a study of Buddhist nuns as portrayed in the Biqiuni zhuan, Valentina Georgieva, points to several issues that characterize female monastics. ${ }^{3} \mathrm{~A}$ fair number of them are from elite

\footnotetext{
${ }^{1}$ For a translation into English, see Kathryn Ann Tsai, Lives of the Nuns, Biographies of Chinese Buddhist Nuns from the Fourth to the Sixth Centuries (Honolulu: University of Hawai'i Press, 1994).

${ }^{2}$ For examples, see, among others, Valentina Georgieva, "Representation of Buddhist Nuns in Chinese Edifying Miracle Tales during the Six Dynasties and the Tang," Journal of Chinese Religions, vol. 24 (1996): 53-55.

${ }^{3}$ Georgieva, Valentina, Buddhist Nuns in China, from the Six Dynasties to the Tang (Ph.D. Leiden University, 2000), 98-170. Similar characteristics are also discussed by Wendi Adamek in a study of two seventh-century memorial niches for Buddhist nuns ("A Niche of Their Own: the Power of Convention in Two Inscriptions for Medieval Chinese Buddhist Nuns," History of Religions, vol. 49, no. 1 (2009)), and in an analysis of two poems inscribed on a memorial niche dedicated to the seventh-century nun Benxing 本行, testifying to female devotional and literary practices ("The Literary Lives of Nuns: Poems Inscribed on a Memorial Niche for the Tang Nun Benxing," T'ang Studies, vol. 27 (2009)).
} 
families. These nuns are very well educated and become recognized as reliable teachers. ${ }^{4}$ Furthermore, many women have supernatural powers as a result of great progress in meditation. They perform and experience miracles. And thirdly, some of them are respected and famous for their ascetic practices, sometimes quite extreme. ${ }^{5}$ Valentina Georgieva refines this portrayal in an article on nuns depicted in miracle tales up to the Tang dynasty, thus covering a period that goes beyond the Biqiuni zhuan. ${ }^{6}$ Typically, miracle stories have a didactic purpose. They provide evidence of miracle powers and show misfortune that strikes non-believers and slanderers of Buddhism. The stories featuring women show many similarities with the biographies, and often rely on the same sources. However, in the miracle stories, nuns show a much lower level of education. According to Georgieva, this lack of education may be due to two factors: on the one hand, nun-scholars are not very numerous, scholarly education being limited to women of the elite, and on the other hand, miracles do not occur as a result of intellectual activity, but rather they coincide with ascetism and meditation. $^{7}$

Apart from texts, inscriptions and memorials also provide interesting material on roles taken up by women. In a study of a collection of seventh-century memorial niches for Chinese Buddhist nuns at Lanfeng shan 嵐峰山, near the city of Anyang, in the modern Henan province, Wendi Adamek shows how these niches provide evidence for an institutional legitimization of nuns and testify to women's agency, bringing to light the collective effort of women to create a sacred site by and for women. ${ }^{8}$ A similar remark is made by Yao Ping, in a

\footnotetext{
${ }^{4}$ However, as rightly indicated by Wendi Adamek ("A Niche of Their Own," 15 and "The Literary Lives of Nuns," 46-47), even if women engaged in literary practices, their works were never included in any anthology, and were not preserved.

${ }^{5}$ As discussed by Wendi Adamek (The Literary Lives of Nuns," 46), extreme ascetic practices of women can possibly be understood in the context of the perception of the female body as the karmic result of past evil deeds. Compared with men, women are indeed often seen as having more karmic residue to get rid of, which might explain why so many women were attracted to a quite extreme ascetic lifestyle. A prominent example of such a medieval Chinese tendency to describe a female body as a body full of bad karma is the fifth century aprocryphal text, the Da'aidao biqiuni jing 大愛道比丘尼經, Sütra on the bhikṣuṇi Mahāprajāpatī, a quite misogynic interpretation of Mahāprajāpatî’s (the Buddha's aunt and stepmother) going forth, a text popular among vinaya masters (on this text, see Ann Heirman, "Chinese Nuns and Their Ordination in Fifth Century China," Journal of the International Association of Chinese Studies, vol. 24, no. 2 (2001): 284-289).

${ }^{6}$ Georgieva, "Representation of Buddhist Nuns."

${ }^{7}$ Georgieva, "Representation of Buddhist Nuns," 52-53 and 64-65.

${ }^{8}$ Adamek, "A Niche of Their Own," 5-6. For a concise overview of the niches, see Adamek, "The Literary Lives of Nuns," 44-45. On women agents, see also Bernard Faure, "Voices of Dissent: Women in Early Chan and Tiantai," Zenbunka kenkyüsho kiyō, vol. 24 (1998), in which he analyzes the case of two Tiantai nuns who, in the eighth century, actively question the male-dominated status quo, a protest which he sees as a rare example of individual female agency (pp.36-42). Wendi Adamek, in contrast, opens up the gender discourse from individual to collective and focuses on what she calls 'nonchallenging collective activity', i.e. the power of the female community to create for itself an own space, without directly challenging the status quo ("A Niche of
} 
detailed study on the life of women in the Tang dynasty, when she argues that the fact that nuns and nuns' inscriptions even exist points to a certain kind of independence. ${ }^{9}$ Yao Ping describes the life of Buddhist nuns as portrayed in tomb inscriptions, mainly focusing on the early Tang and the Zhou dynasty of Empress Wu Zetian. ${ }^{10}$ She sees no signs of inferiority to monks, and argues instead that being a nun is actually a good social position, since many nuns were staff at the imperial court or were sometimes even related to the court. They mostly originated from rich families. In fact, according to Yao Ping, only rich families can really afford for their daughters to become nuns, since women who enter the Buddhist order can no longer be married to a profitable party. ${ }^{11}$ For those women for whom a tomb inscription has been made, Yao Ping then singles out three main reasons to go forth: some young women are forced by their parents to become nuns. As for older women, the tomb inscriptions mainly refer to court ladies (some forced into the Buddhist order) and widows. Becoming a nun thus seems to have been a way for a widow to remain chaste or faithful to her husband even after his death. ${ }^{12}$ Thirdly, some women go forth because of illness. ${ }^{13}$

The biographies studied by Valentina Georgieva and the tomb inscriptions analyzed by Yao Ping highlight the social life of Tang nuns, mostly of an elite family. ${ }^{14}$ The inscriptions further reveal how many women, even when fully ordained, continued to live with their families. ${ }^{15}$ This is also what Jinhua Chen underlines when he discusses that going forth does not necessarily imply that one severs all ties with one's (elite) family. On the contrary, family background continues to play an important role in a monastic's further life and career, while monks and nuns still exert influence on their family members, as shown in

\footnotetext{
Their Own," 23; see also Wendi Adamek, The Mystique of Transmission, On an Early Chan History and Its Contexts (New York: Columbia University Press, 2007), 234-235).

${ }^{9}$ Yao Ping, Tangdai funiu de shengming licheng (Life of Women of the Tang Dynasty) (Shanghai: Shanghai guji chubanshe, 2004), 227.

${ }^{10}$ Yao Ping, Tangdai funü de shengming licheng, 227-246. For a factual analysis of the environment in which Tang dynasty nuns functioned, see also Li Yuzhen's study of Tang engraved inscriptions on nuns' statues or tombs, Tangdai de biqiuni (Nuns of the Tang Dynasty) (Taipei: Taiwan xuesheng shuju, 1989). Li identified 73 nuns, many of whom came from elite families and acquired a relevant position in the monastic community (pp.10-38).

${ }^{11}$ Yao Ping, Tangdai funü de shengming licheng, 234.

${ }^{12}$ Particular cases are adoptive daughters of eunuchs who go forth in order to escape a forced marriage with another eunuch (Yao Ping, Tangdai funü de shengming licheng, 241).

${ }^{13}$ Yao Ping, Tangdai funü de shengming licheng, 235-241.

${ }^{14}$ These women sometimes had considerable financial means, as shown in a study by Amy McNair on donors of the Longmen grottoes, Donors of Longmen (Honolulu: University of Hawai'i Press, 2007), 56-59, where she describes how, in medieval China, some wealthy nuns donated their private fortune for sculptures. In one case, a nun did so explicitly to overcome her female form, 'dedicating the merit of her grotto to all womankind' (p.59).

${ }^{15}$ Yao Ping, Tangdai funü de shengming licheng, 241-246. According to Yao Ping (p.246), this is possibly due to a shortage of places in the nunneries. Still, this might not be the only reason if we consider the high number of monks and nuns living outside the monastery in the Dunhuang region, who apparently opted freely to live with their families rather than in a monastery (see below).
} 
two prominent cases. ${ }^{16}$ The first one is Facheng 法澄 (640-729), a former princely concubine who became a nun after the suicide of her husband. ${ }^{17}$ After having been a popular court chaplain at the court of Empress $\mathrm{Wu}$, she was appointed abbess of a very influential nunnery in Chang'an. The second nun is Qiwei 契微 (720-781) who was raised in a noble Taoist family that had extensive political connections. Against the will of her family, she became a Buddhist nun when she was a teenager. She was trained in the most important Buddhist monasteries and became a famous preacher. Both these ladies had extraordinary careers, closely tied to their family relationships.

Finally, the option of living outside the monastery in a close relationship with one's family members is also pointed out by Hao Chunwen in a study of Dunhuang manuscripts dating from the Late Tang to the Early Song period (roughly the ninth to the eleventh century), probably also dealing with monastics coming from less high-profile families, given the relatively high numbers of monks and nuns mentioned. ${ }^{18}$ Monks and nuns living outside the monastery did so with full permission of their monastic heads. Hao further argues that, in Dunhuang, in contrast to other regions where some monastics also lived outside the monastery, the outside monks and nuns actively participated in monastic events, and were considered by all to be full members of the monastic community.

Despite the life stories of successful Buddhist women described above, nuns continued to be portrayed in rather negative terms in many Buddhist texts, and certainly in those compiled by vinaya masters. This depiction can rightfully be defined as a status quo, since for many centuries it seems to have remained relatively stable. Many researchers, however, several of whom I mentioned above, have shown that this standard story does not give a true picture of the life and activities of Tang Buddhist women and yet it continues to exert a strong influence, women still having to respond to it, even today. ${ }^{19}$ This is not all that surprising though. The basis of the status quo picture has been sanctioned by very influential Tang vinaya masters,

\footnotetext{
${ }^{16}$ Jinhua Chen, "Family Ties and Buddhist Nuns in Tang China: Two Studies," Asia Major, vol. 15, no. 2 (2002). On the persistence of family ties, see also Adamek, "A Niche of Their Own," 10-12.

${ }^{17}$ Equally discussed in Li, Tangdai de biqiuni, 22 and 53-54.

${ }^{18}$ Hao Chunwen, Tang houqi Wudai Songchu Dunhuang sengni de shehui shenghuo (Social Life of Dunhuang Monks and Nuns in the Late Tang, Five Dynasties and Early Song Period) (Beijing: Zhongguo shehui kexue chubanshe, 1998), 76-88. Although it is difficult to obtain exact figures, Hao's research clearly shows that there was a balance between monks and nuns, the latter being slightly more numerous. For the year 788, Hao (p.97) gives 139 monks and 171 nuns; for 800, 197 monks and 209 nuns; for 895, respectively, 447 and 693; and for 936, 519 monks and 450 nuns.

${ }^{19}$ For a discussion, see, among others, Elise Anne DeVido, Taiwan's Buddhist Nuns (Albany: State University of New York Press, 2010), 105-110.
} 
who are still revered today as the founding fathers of Chinese monasticism. Their impressive treatises shaped the Chinese monasteries and built the foundations of an overwhelmingly rich monastic environment. The guidelines they provided were of extreme importance, and continue to be so. But what do these vinaya masters exactly emphasize in their disciplinary treatises when they discuss women and their position in monastic life? While we know, as summarized by Wendi Adamek, referring to The Red Thread of Bernard Faure, that a depiction of women generally involves an idealization of certain kinds of female practices, a demonization of women as seductive and untrustworthy, and a validation of women as adepts, we have less information on what Tang vinaya masters highlight in their commentaries on women and on the arguments and criteria they use to justify their opinions. ${ }^{20}$ This article, therefore, wants to focus on the nuns' institutional story as seen and justified through the eyes of the founding vinaya masters of the Tang period. What topics do they address? What are the main features? What arguments do they use? Which authoritative texts do they refer to? And how unchallenged is their account on women? Although nuns clearly seem to enjoy a higher status and more freedom than is awarded to them by monastic rules or vinaya masters, even to the extent that the monks' incitements often appear to have been merely formal guidelines of a theoretical nature, the way Tang vinaya masters featured women remains an important background picture with far-reaching influence up to the present day. It is to this picture that we now turn our attention.

\section{$\underline{\text { 2. Tang dynasty vinaya masters }}$}

In the first centuries of Chinese Buddhism, no full vinayas had been translated into Chinese and there was a feeling among monastic masters that this situation needed to be improved. ${ }^{21}$ This context changed dramatically when, in the first half of the fifth century, four vinaya translations saw the light. In chronological order, these are: Shisong lü 十誦律 (T.1435), Sarvāstivādavinaya; Sifen lü 四分律 (T.1428), Dharmaguptakavinaya; Mohesengqi lü 摩訶 僧祇律 (T.1425), Mahāsāmp̣hikavinaya; and Mishasai bu hexi wufen lü 彌沙塞部和䤈 五分律 (T.1421), Mahiśsāsakavinaya. ${ }^{22}$ Much later, in the beginning of the eighth century,

\footnotetext{
${ }^{20}$ Adamek, "A Niche of Their Own," 5; Bernard Faure, The Red Thread (Princeton: Princeton University Press, 1998).

${ }^{21}$ See, among others, Tōru Funayama, "The Acceptance of Buddhist Precepts by the Chinese in the Fifth Century," Journal of Asian History, vol. 38, no. 2 (2004): 97-101; Ann Heirman, "Vinaya from India to China," in Ann Heirman and Stephan-Peter Bumbacher, eds., The Spread of Buddhism (Leiden: Brill, 2007), 169-174.

${ }^{22}$ For details, see, among others, Funayama, "The Acceptance of Buddhist Precepts," 101-104; Heirman, "Vinaya from India to China," 175-177.
} 
the traveler monk Yijing 義 淨 (635-713) translated large parts of the Mūlasarvāstivādavinaya (Genbenshuoyiqieyou bu pi'naiye 根本說一切有部毘奈耶, T.1442-T.1451), as well as other vinaya texts belonging to the same school. ${ }^{23}$ It was the Dharmaguptakavinaya (Sifen lü 四 分 律) that gradually became dominant, strongly stimulated by influential vinaya masters. Around 705-710, it was even imposed, by imperial decree, as the only valid vinaya for ordinations in the Chinese empire. ${ }^{24}$

The massive translation of disciplinary texts raised interest in vinaya studies, and more and more masters entered the field. It gave rise to several vinaya traditions, often focusing on the Dharmaguptakavinaya. Some of these traditions were later called Vinaya Schools (律宗 Lüzong), of which the first and most important one is the so-called Vinaya School of Nanshan (Nanshan lüzong 南山律宗), the start of which is commonly attributed to the monk Daoxuan 道宣 (596-667). ${ }^{25}$ This school promoted the Dharmaguptakavinaya as the basis on which the first Chinese ordinations were relying. ${ }^{26}$ In 615 , Daoxuan received his full ordination from the famous vinaya master Zhishou 智首 (567-635) in whose tradition he continued his studies. ${ }^{27}$ As abbot of the Ximing (西明) monastery near the capital Chang'an, Daoxuan wrote several

\footnotetext{
${ }^{23}$ Of the Mülasarvāstivādavinaya, a Tibetan translation as well as large parts of the Sanskrit text are extant (see Akira Yuyama, A Systematic Survey of Buddhist Sanskrit Literature, Erster Teil: Vinaya-Text (Wiesbaden: Franz Steiner Verlag, 1979), 12-33).

${ }^{24}$ See Tang Yongtong, Han Wei Liang-Jin Nanbeichao Fojiaoshi (History of Buddhism of the Period of Han, Wei, Two Jin and the Southern and Northern Dynasties) (Banqiao: Luotuo Chubanshe, 1996 (first edition 1938)), vol. 2, 828-829; Ann Heirman, "Can we Trace the Early Dharmaguptakas?" T'oung Pao, vol. LXXXVIII (2002): 419-423. On the predominance of the Dharmaguptakavinaya, see also Funayama, "The Acceptance of Buddhist Precepts," 113-115.

${ }^{25}$ For an overview of vinaya masters, see Heirman, "Can we Trace the Early Dharmaguptakas?" 410-413 and Laszló Hankó, Der Ursprung der japanischen Vinaya-Schule Risshū 律宗 und die Entwicklung ihrer Lehre und Praxis (Göttingen: Cuvillier Verlag, 2003), 10-16 and 356. There is, however, an intensive scholarly debate on the use of the term 'School(s)' in the period before the Song dynasty (see, among others, Tang Yongtong, "Lun Zhongguo fojiao wu 'shi zong' (Discussion on why Chinese Buddhism does not have 'Ten Schools')." Zhexue yanjiu, 3 (1962), 47-54 and "Zhongguo fojiao zongpai wenti bu lun (Further Discussions on Chinese Buddhist Schools)." Beijing Daxue xuebao, 5 (1963), 1-18; Stanley Weinstein, "Schools of Buddhism: Chinese Buddhism," in Mircea Eliade, ed., Encyclopedia of Religion (New York: Macmillan, 1987), vol. 2: 482-87. In this context, a recent study by Jinhua Chen ("Vinaya Texts and Transmission History: New Perspectives and Methods," paper presented at the Research Center for Buddhist Texts and Arts, Peking University, August 2013) addresses the complex issue of early lineages of vinaya masters, as well as the essential role played in promoting the Dharmaguptakavinaya by the monks Daoyun 道雲 (6th century, d.u.) and Zhishou 智首(567-633), Daoxuan's master. Although Daoxuan was certainly an inspiring master, it is not at all sure that he considered himself as the founder of a separate school. Still, in later centuries, he was recognized as such.

${ }^{26}$ Daoxuan, T.2060, p.620c2-3 and Sifen lï shanfan buque xingshi chao 四分律刪繁補關行事鈔, An Abridged and Explanatory Commentary on the Dharmaguptakavinaya, T.1804, p.51c7-9.

${ }^{27}$ For a detailed biographical account of master Zhishou, see, in particular, Jinhua Chen, "An Alternative View of the Meditation Tradition in China: Meditation in the Life and Works of Daoxuan (596-667)," T'oung Pao, vol. LXXXVIII (2002): 375-384.
} 
influential commentaries and actively promoted Buddhism at the imperial court. ${ }^{28} \mathrm{He}$ emphasizes that the Dharmaguptakavinaya is the basic vinaya text, but that, if needed, other vinayas can be consulted. ${ }^{29}$ In three of his commentaries, Daoxuan discusses how women became part of the monastic community, and how their position should be regarded. These commentaries are the Sifen lü shanfan buque xingshi chao 四分律刪繁補閶行事鈔, An Abridged and Explanatory Commentary on the Dharmaguptakavinaya (T.1804), the Sifen lï shanbu suiji jiemo 四分律刪補隨機羯磨, An Abridged and Explanatory Karmavācanā of the Dharmaguptakavinaya (T.1808) and the Sifen lü biqiuni chao 四分律比丘尼鈔, Commentary on the [Part for] Bhikṣuṇis of the Dharmaguptakavinaya (W Vol.64, pp.50-192).

In two other vinaya traditions, which also developed at the beginning of the Tang dynasty, the position of women is equally discussed. These two traditions, however, were gradually superseded by Daoxuan's Nanshan lüzong that became the Vinaya School of China, which is still a point of reference today. The oldest of these two vinaya traditions is the one led by the monk Fali 法礪 (569-635) who lived in Xiangzhou 相州 (in the modern province of Henan), hence the name Xiangbu 相部, 'Xiang tradition' ${ }^{30}$ In his Sifen lü shu 四分律疏, Commentary on the Dharmaguptakavinaya (W Vol.65, pp.357-975), he comments extensively on the position of nuns, in relation to the monastic community. Dissatisfied with Fali's study, the monk Huaisu 懷素 (ca. 634-697), who was originally a disciple of Fali, compiled his own commentaries, thus starting another vinaya tradition, the Dongta 東塔 tradition, named after a stūpa in the monastery he lived in (in the capital Chang'an). ${ }^{31}$ In his Sifen lü kaizong ji 四分律開宗記, Introduction to the Teachings of the Dharmaguptakavinaya (W Vol.66, pp.667-992 to Vol.67, pp.1-216), Huaisu discusses the status of Buddhist nuns.

\footnotetext{
${ }^{28}$ For details, see Robin B. Wagner, Buddhism, Biography and Power: A Study of Daoxuan's "Continued Lives of Eminent Monks" (Ph.D. Harvard University, 1995), 46-90; Yifa, The Origins of Buddhist Monastic Codes in China, An Annotated Translation and Study of the Chanyuan Qinggui (Honolulu: University of Hawai'i Press, 2002), 23-28.

${ }^{29}$ Daoxuan, T.1804, p.2b19-20 and Sifen lü biqiuni chao 四分律比丘尼鈔, Commentary on the [Part for] Bhikșuñs of the Dharmaguptakavinaya, W Vol.64, p.50b5-6. See also Zhihui Tan, Daoxuan's Vision of Jetavana, Imagining a Utopian Monastery in Early Tang (Ph.D. University of Arizona, 2002), 68-69.

${ }^{30}$ For a biography, see Daoxuan, Xu gaoseng zhuan 續高僧傳, Further Biographies of Eminent Monks, T.2060, p.615c4-29.

${ }^{31}$ For a biography, see Zanning 贊寧, Song gaoseng zhuan 宋高僧傳, Song Biographies of Eminent Monks, T.2061, pp.792b25-793a10. There is discussion on the exact dates of Huaisu. Alternative dates are 625-698 and 634-707 (see Wang Jianguang, Zhongguo lüzong tongshi (General History of the Chinese Vinaya Schools) (Nanjing: Fenghuang chubanshe, 2008), 311).
} 
The vinaya masters described above shaped the disciplinary background of Chinese monastic institutions, and their commentaries became prominent guidelines for all monastic activities. Daoxuan particularly acquired the status of standard reference point for Chinese monasticism. It is therefore not surprising that the masters' viewpoints on the position and the role of women in the Buddhist monasteries were very influential and continue to be so, giving rise to a standardized, and therefore potential status quo account on women.

\section{The role and position of Buddhist nuns in the Tang vinaya masters' accounts.}

Among the Tang dynasty founding vinaya masters, the monk Daoxuan is undoubtedly the most productive one and the one who expresses his views on the role and position of nuns most extensively. He is also the most influential one, his commentaries still being frequently quoted to the present day. Other vinaya masters say relatively less about women and nuns. We have therefore taken Daoxuan as the central master, adding his colleagues' views to his opinions. When analyzing Daoxuan's commentaries, four themes clearly come to the fore: Mahāprajāpatī and her request to become a fully ordained nun; the advantages of the eight important rules (gurudharma); the dual ordination of nuns; and the concept of filial piety.

\subsection{Mahāprajāpatī asking for ordination}

Daoxuan discusses the ordination of the first Buddhist nuns extensively in his Sifen lü biqiuni chao, W Vol.64, pp.50-192. In the introduction to his commentary (p.50), he sums up the major points, and recalls that it was Mahāprajāpatī (the Buddha's aunt and stepmother), who, together with 500 very knowledgeable Sākya women, was the first to request to be fully ordained into the Buddhist community. These women had their hair shaved, put on monastic clothing, and eagerly asked the Buddha for permission to become bhikṣuṇis. In fact, Daoxuan adds, it was the monk Ānanda who (after a first refusal of the Buddha to accept the request) was worried about the women's tears and asked the Buddha to let them enter the Buddhist order. The Buddha then changed his mind, but warned that the Buddhist community would now last only for 500 years rather than for 1000 years. He (therefore) imposed, as a condition for the women's ordination, eight important rules (gurudharmas, that make women institutionally subordinate to monks). ${ }^{32}$ Mahāprajāpatī accepted them.

\footnotetext{
${ }^{32}$ For details on these rules, see, among many others, Isaline Blew Horner, Women under Primitive Buddhism: Laywomen and Almswomen (New York: E. P. Dutton and Company, 1930), 118-161; Ute Hüsken, Die Vorschriften für die buddhistische Nonnengemeinde im Vinaya-Pitaka der Theravādin (Berlin: Dietrich Reimer
} 
Further on in his commentary (p.113a12-114b7), Daoxuan gives more details. He first refers (p.113a12-17) to the Mahiśāsakavinaya (T.1421, p.185b19-c29), summarizing the story of the going forth of Mahāprajāpatī. He stresses that, when Mahāprajāpatī asked the Buddha to be admitted into the monastic order, she was not accepted because earlier Buddhas also did not allow it. Still following the Mahisíāsakavinaya, he also states that women can rely very well on the Buddha while at home, and still cut their hair, wear the kasṣaya (the standard monastic cloth), eagerly follow the path and obtain all kinds of merit. Future Buddhas will all say the same. ${ }^{33}$

五分云。㫿曇彌白佛言。願聽女人出家受戒。佛言。止止。莫作是語。所以者 何。往古諸佛皆不聽女人出家。諸人皆自依於佛。在家剃髮著袈乷。勤行精進。 獲得果證。未來諸佛亦復如是。(W Vol.64, p.113a12-15)

The Mahis'āsakavinaya says: "Gautamī asked the Buddha: 'Please allow women to go forth and to obtain full ordination.' The Buddha replied: 'Wait, wait. Do not say such a thing. Why is this? All the Buddhas of the past did not allow women to go forth. (Still,) they [= women] all relied on the Buddha. While at home, they cut the hair and wore the kāsa âya. They eagerly made progress and obtained merit. The Buddhas of the future will also be like this."”

Daoxuan then skips the rest of the story to come to his second point, arguing that it was only after the Buddha had given the eight gurudharmas to Mahāprajāpatī, that she really got the permission to go forth. Daoxuan clearly takes a critical view on the admission of women into the order when he further refers (p.113a17-b12) to the Pinimu jing 毘尼母經, Vinaya Mātrkāa Sūtra, a commentary on the prātimokșasūtra of an unknown school (T.1463, p.818b16-c8), translated at the end of the fourth or at the beginning of the fifth century ${ }^{34}$ : the monk Ānanda, who intervened on behalf of Mahāprajāpatī, is blamed by the monk Kāśyapa for ten reasons:

Verlag, 1997), 345-360; Ann Heirman and Tzu-Lung Chiu, "The Gurudharmas in Taiwanese Buddhist Nunneries," Buddhist Studies Review, vol. 29, no. 2 (2012): 276-280. Most vinayas contain very similar rules, although the order can be different (for an overview, see Jin-il Chung, "Gurudharma und Aștau Gurudharmāḥ," Indo-Iranian Journal, vol. 42 (1999): 229.

${ }^{33}$ The same idea (with a reference to the Mahissāsakavinaya) is also highlighted by the monk Huaisu in his Sifen lü kaizong ji 四分律開宗記 (Introduction to the Teachings of the Dharmagupatakavinaya), W Vol.67, pp.162b17-163a4. See also Anālayo ("Mahāpajāpatī’s Going Forth in the Madhyama-āgama," Journal of Buddhist Ethics, vol. 18 (2011): 292), who, on the basis of a detailed analysis of the account of Mahāprajāpatī's going forth as related in the Madhyamāgama (a major sūtra text), suggests that 'for the Buddha to tell Mahāpajāpatī Gotamī that she can live a semi-monastic life at home quite possibly constitutes an early piece of the narrative'.

${ }^{34}$ Paul Demiéville, Hubert Durt and Anna Seidel, Répertoire du canon bouddhique sino-japonais, édition de Taishō (Taishō Shinshū Daizōkyō) (Paris: Librairie d'Amérique et d'Orient; Tokyo: Maison Franco-Japonaise, 1978), 125; Yuyama, A Systematic Survey, 44. On the title, see Shayne Clarke, "Vinaya Mātrkā - Mother of the Monastic Codes, or just Another Set of Lists? A Response to Frauwallner's Handling of the Mahāsāmghika Vinaya," Indo-Iranian Journal, vol. 47 (2004): 87. The affiliation of the text is not yet established (for detailed references, see Anālayo, "Mahāpajāpatî’s Going Forth," 270-271, note 11). 
(1) if women had not gone forth, all dānapatis (benefactors) would have knelt at the side of the road and offered the śramanas a lot of food; (2) equally, they would have given lots of clothes and bedding, and have offered it to the śramanas on the road; (3) when riding on the road, the same dannapatis would have prostrated themselves before the śramanas they encountered; (4) and would have asked them to step on their hair; (5) in a most respectful way, they would have asked the śramanas to go to their homes to receive offerings; (6) they would have swept the floor, taken off their clothes and put them on the floor, and invited the śramanas to sit on them; (7) with their own clothes, they would have cleaned the feet of the śramanas; (8) or they would have dusted off the monks' feet with their hair; (9) the Buddhist monks would have been superior to all non-Buddhists; (10) and the dharma would have stayed for 1000 years, instead of for $500 .{ }^{35}$

Clearly, Daoxuan is of the opinion that Buddhist monks lost a lot of respect and revenue when women were admitted into the order. Apart from this, he advances other arguments against the acceptance of women: earlier Buddhas also did not allow it, and it is very possible for women to rely on the Buddha whilst remaining at home. There was even the risk that the Buddhist dharma would only have lasted half as long, a danger that could only be averted by imposing on women the eight important rules. Naturally, it explains the importance of unrelenting adherence to these rules, which is the next issue Daoxuan turns to.

\subsection{Advantages of the eight important rules (gurudharma)}

When discussing the gurudharmas, Daoxuan starts by saying that their most important aim is to prevent the dharma lasting only 500 years, safeguarding it for its original 1000 years (W Vol.64, p.113b12-14). ${ }^{36}$

\footnotetext{
${ }^{35}$ This passage is quite popular among vinaya masters, and is also referred to by Fali in his Sifen lü shu 四分律 疏 (Commentary on the Dharmaguptakavinaya), W Vol.65, p.920b10-17 and in the Sifen lü shu shizong yi ji 四 分律疏飾宗義記 (Embellished Exposition on the Commentary on the Dharmaguptakavinaya), a subcommentary on Fali's text, written by the monk Dingbin 定賓 (beginning of eighth century), W Vol.66, p.563a14-b2. Also Huaisu refers to a similar passage in his Sifen lï kaizong ji, W Vol.67, p.164b1-15. On the same kind of reproaches uttered by the Buddha himself as mentioned in the Madhyamāgama, see Anālayo, "Mahāpajāpatî̀s Going Forth," 285-287, 301-306, who sees them as outbursts of the community of monks who could have become increasingly nervous about the independent behavior of nuns and their close relationship with the laity.

${ }^{36}$ In this context, it is interesting to note that when Daoxuan discusses the mother of his vinaya teacher Zhishou (who became a nun with the dharma name Fashi 法施), he explicitly mentions that she faithfully followed the eight important rules (Xu gaoseng zhuan, T.2060, pp.614a11-24). He further describes her as a distinguished and learned nun, who, however, failed to get her son ordained early, maybe because Zhishou's teacher did not fully acknowledge Fashi's judgment, considering Zhishou to not be mature enough (with many thanks to Jinhua Chen for pointing out this passage to me; see also Chen, "An Alternative View," 375-6).
} 


\section{見論云。所以不聽女人出家者。為敬法故。若度女人出家。正法五百歲不住。 由世尊制比丘尼行八敬故。正法還得千年。(W Vol.64, p.113b12-14)}

The reason why the Shanjian lü piposha says that women are not allowed to go forth is because of the eight important rules. ${ }^{37}$ If women go forth, the True Law will not remain for five hundred years (more). Since the World-Honored One has given the eight important rules to the bhikșunīs, the True Law can still remain for one thousand years.

The eight rules thus serve as a protection against moral deprivation (pp.113b16-114a2). Still, after 1000 years, the dharma will start to decay and 1100 years after the demise of the Buddha, monks will marry, will be matchmakers, and will slander the vinaya. For this prediction Daoxuan refers (p.113b14-16) to the Moye jing 摩 耶 經, Mahāmāyāsūtra?, T.383, p.1013c14-15, a sütra on the Buddha's mother Māyā, translated into Chinese during the Southern Qi dynasty (479-502). ${ }^{38}$ Obviously, for Daoxuan, the gurudharmas are of utmost importance to prevent this from happening even sooner.

\section{摩耶經云。千一百歲已。諸比丘等如世俗人嫁娶。行媒。於大眾中毀謗毗尼。 (W Vol.64, p.113b14-16)}

The Moye jing says: "After one thousand and one hundred years, bhikșus will marry like common men. They will acts as go-betweens and, in the community, they will slander the vinaya.

After having presented an overview of the eight rules (p.114a2-10), the order of which corresponds to the Dharmaguptakavinaya (T.1428, p.923a28-b17), Daoxuan elaborates on a few of them. He first refers (p.114a10-11) to the fifth gurudhama, as given in the account of the establishment of the order of nuns in the Zhong ahan jing 中阿含經, Madhyamāgama, translated into Chinese at the end of the fourth century (T.26, p.606a16-20): before nuns can ask monks questions about sūtra, vinaya and abhidharma, they should first ask for

\footnotetext{
${ }^{37}$ This refers to T.1462, p.796c20-23. For more details on this text, see note 72 .

${ }^{38}$ Demiéville et al., Répertoire du canon bouddhique sino-japonais, 48 and 243. The Moye jing is a sütra on Māyā, the mother of Śākyamuni Buddha. According to tradition, Māyā passed away a week after having given birth. The Moye jing has two major parts: it first relates how the Buddha went to preach the dharma to his mother who was reborn in the Heaven of the Thirty-three Gods. Second, it describes how Māyā, when she learned of the death of her son, descended from heaven to see his body for the last time. The sütra further tells of those who will propagate the dharma in the 1500 years following the Buddha's death, and it predicts what will happen. On this text and its prediction, see, in particular, Jan Nattier, Once Upon a Future Time, Studies in a Buddhist Prophecy of Decline (Berkeley: Asian Humanities Press, 1991), 168-170.
} 
permission. ${ }^{39}$ Only after having been allowed to do so can nuns address monks on these issues. He further refers (p.114a11-16) to (a passage of) the first gurudharma as mentioned by the Mahāsāṃghikavinaya (T.1425, p.471b5-11): when nuns go to a monks' monastery they must honor all monks, bowing their heads at the monks' feet. ${ }^{40}$ Old and sick nuns can do so as much as their strength permits. If they are not able to greet all the monks, they can pay obeisance orally. When monks go to a nunnery, nuns should never revile them nor point out any faults. ${ }^{41}$ On the other hand, monks can point out (real) faults of nuns. ${ }^{42}$ Daoxuan thus insists on the hierarchical subordination of nuns, while making sure that women are never allowed to reprimand or embarrass monks in any way. ${ }^{43}$ This is exemplified further with a reference (p.114a17-18) to the fifth gurudharma, as mentioned by the Da'aidao biqiuni jing 大愛道比丘尼經, Sūtra on the bhikṣun̄i Mahāprajāpatī, a vinaya text strongly influenced by Mahāyāna ideas, possibly translated in the first half of the fifth century (T.1478,

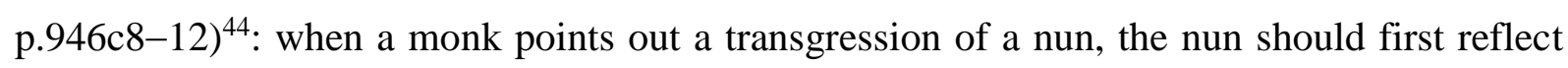
by herself, and certainly never shout. According to Daoxuan (p.114b18, corresponding to T.1478, p.950b29-c1), this demonstrates that nuns should look upon monks in the same way as they look upon the Buddha.

\section{又比丘尼敬比丘僧。視之如佛。(W Vol.64, p.114a18)}

Further, when bhikșun̄is honor the bhikșusamgha, they look upon them just as they look upon the Buddha.

\footnotetext{
${ }^{39}$ For a translation and a detailed analysis of this account, which is probably related to the Sarvāstivāda tradition, see Anālayo, "Mahāpajāpatī’s Going Forth".

${ }^{40}$ For a translation into English, see Akira Hirakawa (in collaboration with Zenno Ikuno and Paul Groner), Monastic Discipline for the Buddhist Nuns, An English Translation of the Chinese Text of the MahāsāmghikaBhikșuñi-Vinaya (Patna: K.P. Jayaswal Research Institute, 1982): 49-50.

${ }^{41}$ A bit further in his commentary (p.114b2-3), Daoxuan also refers to the third gurudharma mentioned by the Mahāsāmghikavinaya (T.1425, p.474c4-5): only if a monk is a close relative, a nun can softly admonish him, but she should never scold him (for a translation, see Hirakawa, Monastic Discipline for the Buddhist Nuns, 82). By selecting this passage, Daoxuan underlines that family ties remain important.

${ }^{42}$ The latter statement is in fact part of the third (and not the first) gurudharma of the Mahāsämghikavinaya (T.1425, p.474c3), and has been inserted here by Daoxuan. For a full translation, see Hirakawa, Monastic Discipline for the Buddhist Nuns, 83.

${ }^{43}$ Referring (p.114a18-b2) to the Dharmaguptakavinaya (T.1428, p.929c17-21), Daoxuan also states that, if bhikṣuṇis (nuns), śikṣamāṇās (probationers) or śrāmaṇerīs (novices) offend bhikṣus (monks), one should make it stop. If they do not change their attitude and do not repent, one should perform a formal act (jiemo 羯磨, karman) against those nuns who are their teachers to prohibit them from further teaching any disciples.

${ }^{44}$ Although the Da'aidao biqiuni jing presents itself as a translation, Akira Hirakawa (Ritsuzō no kenkyū 律蔵の 研究 (A Study of the Vinaya-Pițaka) (Tokyo: Sankibō Busshorin, 1970), 273-274) does not exclude that the text is a Chinese compilation. As I have shown elsewhere ("Chinese Nuns and Their Ordination in Fifth Century China," 284-289), the Da'aidao biqiuni jing contains many misogynic ideas, while significantly changing the account of the eight gurudharmas to the detriment of nuns.
} 
The above is a very strong statement, in full support of male dominance. In this context, it is not surprising that Daoxuan adds (p.114b4-5), referring to the Dharmaguptakavinaya (T.1428, p.930b18-c4), that if a monk summons a nun who deserves admonishment, she should always go. If she does not obey, she must be reprimanded.

As can be seen, Daoxuan attaches quite some importance to the gurudharmas. For him, they are an essential buffer against moral deprivation. Strict adherence is therefore a must. He insists on the hierarchical subordination of nuns to monks, and seems particularly concerned with making sure that women can never, in any way, reprimand a monk. In that context, he even puts monks on a par with the Buddha. Daoxuan always takes great care to support all his statements with authoritative text fragments, which he carefully selects. This is also the case when he answers, for himself and for his audience, the crucial question about why nuns have to depend on monks. He answers with a reference (p.114b5-7) to the above-mentioned Da'aidao biqiuni jing (T.1478, p.952b15-17): women are only confused, they do not want to learn and only know about small things. Therefore, they should depend on monks. With this answer, Daoxuan not only puts women on a lower hierarchical level, he also declares women emotionally and intellectually weaker. ${ }^{45}$

問。何故制尼依僧耶。答。愛道尼經云。女人但欲惑色。益壽畜弟子。亦不欲 學問。但知須臾之事。故依僧也。(W Vol.64, p.114b5-7)

Question: why is it stipulated that bhikșun̄s have to rely on the (bhikșu)samgha? Answer: the Da'aidao biqiuni jing says: "Women only want delusion. Their whole life, they take pupils, (but) they do not want to learn and only know trivial things. Therefore, they rely on the (bhikșu)samgha.

The above question and answer equally appear in two other commentaries of Daoxuan: in his Sifen lü shanfan buque xingshi chao (T.1804, p.153b5-7) in a discussion on ordination procedures for nuns, and, secondly, in a remark on the full ordination ceremony for nuns, in his Sifen lü shanbu suiji jiemo (T.1808, p.498c20-21). In the latter passage, he develops his

\footnotetext{
${ }^{45}$ In a similar vein, also Daoxuan's ordination master, the monk Zhishou, reminds us in his Sifen lü shu 四分律 疏 (Commentary on the Dharmaguptakavinaya), W Vol.66, p.657b16-18, of male superiority in the monastic institutions: when discussing the bi-monthly instruction that nuns receive from monks (in accordance with the eight important rules), the text explains that nuns are people of the weaker sex (ni shi nü ruo zhi ren 尼是女弱之 人), and therefore in need of protection. Similarly, the monk Huaisu speaks of the weak will of women when he explains why the Buddha did at first not allow them to enter the Buddhist community (Sifen lï kaizong ji, W Vol.67, p.163a18-b1).
} 
reasoning further with a reference to the Da zhidu lun 大智度論, Mahāprajñāpāramitā Śāstra (T.1509, p.85a9-11), translated (or compiled) by Kumārajīva around the beginning of the fifth century. ${ }^{46}$ The Da zhidu lun first states that, because nuns need a lot of vinaya explanation, they always should follow monks, but can be in front of śrämaneras (novices). Yet, the $D a$ zhidu lun continues, since the Buddha in fact considers this order not to be in accordance with the appropriate customs, nuns should come after the novices.

\section{智度論云。尼得無量律儀故。應次比丘後。佛以儀式不便故在沙爾後。(T.1808, p.498c20-21)}

The (Da) zhidu lun says: "Because bhikșun̄is get an immeasurable amount (of precepts) restraining conduct, they should come second to bhikșus. Since the Buddha considers this ceremonial order not to be appropriate, they (in fact) come second to śrāmaneras."

This discussion on the proper order of monastics reminds us of the gurudharma that states that nuns always follow monks, whatever their seniority might be, but the gurudharma does not say anything about novices. ${ }^{47} \mathrm{~A}$ clear deterioration of the position of nuns appears, however, in the Da'aidao biqiuni jing, a text Daoxuan is well acquainted with, as we have seen above. In this text, it is stated that women can be compared to venomous snakes. Since, even when a snake is dead, people still fear it - the venom still being there -, women should pay respect even to a male novice of only eight years old (T.1478, p.949b22-c2). Although Daoxuan does not directly point to this statement, it is probably not coincidental that he concludes his discussion on the ordination procedure of nuns with what seems to be one of his favorite references to the Da'aidao biqiuni jing: women are only confused, do not want to learn and only know about small things. Therefore, they should depend on monks. ${ }^{48}$

The importance of the eight gurudharmas is also focused upon by the monk Fali in his Sifen lü shu, W Vol.65, pp.365b3-367a4: in a discussion on the different ways to obtain a full ordination, the question arises as to why the Sapoduo pini piposha 薩婆多毘尼毘婆沙, a

\footnotetext{
${ }^{46}$ Cf. Demiéville et al., Répertoire du canon bouddhique sino-japonais, 128 and Paul Williams, Mahāyāna Buddhism, The Doctrinal Foundations (London: Routledge, 1989), 74-75.

${ }^{47}$ See for instance, Dharmaguptakavinaya, T.1428, p.923a28-b1: 'Even when a nun has been ordained for one hundred years, she must rise up from her seat when seeing a newly ordained monk, and she must pay obeisance and offer him a place to sit.' The traditional story relates how Mahāprajāpatī protested against this and asked to be allowed to pay obeisance according to seniority. This request is denied (for details, see Heirman, "Chinese Nuns and Their Ordination in Fifth Century China," 278-284). Mahāprajāpatî’s latter request and the subsequent denial are equally highlighted by Fali in his Sifen lï shu, W Vol.65, p.920a16-b10, with a reference to the Mahīśāsakavinaya, T.1421, p.186a7-25.

${ }^{48}$ On the bad influence of women as perceived by Daoxuan in a context different from vinaya, see Bernard Faure, The Power of Denial (Princeton: Princeton University Press, 2003), 55
} 
commentary on the Sarvāstivādavinaya (T.1440, p.512a25-b2), explicitly excludes the possibility of the Buddha personally inviting a woman to become a member of the monastic community without any further formal acts, while the Pinimu jing 毘尼母經, Vinaya Mātrkāa Sütra (T.1463, p.801b11-12), does mention this possibility. ${ }^{49}$ Fali suggests that, at the time of the Buddha, there was a fear that gossip would arise if the Buddha (as a former prince) accepted palace women into the monastic community. People might think it was for his enjoyment (based on T.1440, p.512c1-5). Therefore, the Sapoduo pini piposha does not list this ordination method. It is listed in the Pinimu jing because that text focuses on women who do not belong to the palace.

問多論三局。僧中何故善來不度女人者。答為止誹謗故。若佛自度女人。外道 當言㫿曇本在王宮之中。今雖出家。還度女人。以自娛樂。為息此謗故。若爾 何故此律母等善來度女。答此謂宮外女人。若爾宮外女人應無譏染。譏染義齊。 (W Vol.65, p.365b12-15)

Question: Why is it that in the three cases (= the three ordination methods) of the Duo lun (Sarvāstivāda commentary) (women) are not ordained in the samgha through personal invitation (shan lai 善來, ehi bhikșuṇ) ? ${ }^{50}$ Answer: This is to stop gossip. If the Buddha ordains women himself, non-Buddhists will say: "Gautamī used to live in the kings' palace. Now, although she goes forth, if he ordains women himself, it is for his own pleasure." It is to avoid this gossip [that the Buddha does not personally invite women to be nuns]. [Question:] If this is the case, why does this Vinaya Mātrka then lists the possibility of an ordination through personal invitation? Answer: This means that it refers to women who come from outside the palace.

Still, Fali continues, there must be more to it than that. In fact, according to him, the Sapoduo pini piposha, apart from Mahāprajāpatī being a palace woman, also wants to underline that

\footnotetext{
49 The Sapoduo pini piposha has probably been translated into Chinese after the translation of the Sarvāstivādavinaya and before 431 (see Yuyama, A Systematic Survey, 8-9).

In "Ursprung und Wandel der Aufnahme von Frauen in den buddhistischen Orden nach der kanonischen Überlieferung - eine Randbemerkung," Annual of the Sanko Research Institute of the Studies of Buddhism, vol. 37 (2006): 12-14, Jin-il Chung argues that it is not impossible that there was once a stage in early Buddhism when nuns, just as monks, could indeed be personally invited by the Buddha to become full members of the Buddhist monastic community.

${ }^{50}$ This probably refers to the three methods for ordination as given by the Sapoduo bu pini modelejia 薩婆多部 毘尼摩得勒伽 *Sarvāstivādavinayamātrka (T.1441, p.594b1-2): 比丘尼受具足戒有三種受。一受八敬法。 二遣使。三二部僧。現前白四羯磨。'There are three kinds of full ordination for bhiksunūs: 1) an ordination through the eight important rules (as was the case for Mahāprajāpatī); 2) an ordination through a messenger (in case it is too dangerous for a woman to go out of the nunnery to get her ordination at the monks' monastery, see Sarvāstivādavinaya, T.1435, p.295b13-296a22); 3) an ordination through a jñapticaturthakarman ceremony in both communities (the standard procedure; for details, see Ann Heirman, The Discipline in Four Parts, Rules for Nuns According to the Dharmaguptakavinaya (Delhi: Motilal Banarsidass, 2002), part I, pp.75-8).' These ordination methods are further explained by the Sapoduo pini piposha (T.1440, p.512a25-b2) mentioned above by Fali.
} 
women are very slow and thus need the extra help of the eight important rules. So, there is no reason to leave the possibility of a personal invitation open (W Vol.65, pp.365b18-366a2).

女性多慢。又是姨母並是宮內。須以敬法往要。即為受法。既八敬得戒。何用 善來。(W Vol.65, pp.365b18-366a2)

The nature of women is very slow. On top of that, she (Mahāprajāpatī) is his maternal aunt and a lady of the palace. One needs to proceed with the important rules. As for ordination, she can obtain the precepts through the eight important rules. Why should there be any need for a personal invitation?

This remains the central idea in Fali's very technical, further development of this issue: women, contrary to men, are very slow and emotional. They need the eight important rules (p.366b11-12).

\subsection{Dual ordination: institutional dependence on monks}

Given the importance of the eight important rules, and the lower position women occupy in the Buddhist monastic institution, it comes as no surprise that Daoxuan pleads for a strict adherence to one of the most influential gurudharma rules, namely the one that says that 'after a woman has been trained for two years in the six rules as a probationer (śikșamānāa), the ordination ceremony must be carried out in both orders (first in the nuns' order, and then in the monks' order). ${ }^{51}$ Such a dual ordination needs to take place in the presence of a legal quorum, first of nun witnesses and then of monk witnesses. ${ }^{52}$ In China, however, due to a lack of nun witnesses, the first ordinations of nuns (fourth century AD) took place in the presence of monk witnesses only, and this quickly gave rise to discussions, certainly after the translation of full vinayas in the beginning of the fifth century. A so-called 'second ordination' became possible only when in ca. 433 two groups of Sinhalese nuns arrived in China. Now a dual ordination could be held, and a legally more recognized nuns' ordination line could take off. ${ }^{53}$

In his Sifen lü shanfan buque xingshi chao, Daoxuan discusses the introduction of a dual ordination for nuns in China (T.1804, pp.51c9-22). He states that the first ordination

\footnotetext{
${ }^{51}$ Dharmaguptakavinaya, T.1428, p.923b8-10. A probationer is a status between a novice and a nun, only applicable to women. The training typically starts at the age of 18 . For a detailed discussion on the probationer, see, among others, Chung, "Ursprung und Wandel der Aufnahme von Frauen in den buddhistischen Orden" and Ann Heirman, "Where is the Probationer in the Chinese Buddhist Nunneries?" Zeitschrift Der Deutschen Morgenlandischen Gesellschaft, vol. 158, no. 1 (2008).

52 The number of witnesses is usually ten (for details, see Heirman, "Chinese Nuns and Their Ordination in Fifth Century China," 294-295, notes 88 and 89).

${ }^{53}$ For details, see, among others, Heirman, "Chinese Nuns and Their Ordination in Fifth Century China," 293298; Ann Heirman, "Buddhist Nuns: Between Past and Present," Numen, vol. 58 (2011): 609-625.
} 
(without nun witnesses) has to be seen as valid, the 'second ceremony' having only enhanced its value, a view that had been defended before by the master Gunavarman (求那咙摩, 367431). As for this second ceremony, Daoxuan draws special attention to two issues: the Sinhalese nuns needed to learn Chinese, and their number needed to be ten. ${ }^{54}$

又後有師子國尼八人。來至云。宋地未經有尼何得二眾受戒。摩云。尼不作本 法者。得戒得罪 [...] 諸尼苦求更受。答曰。善哉夫戒定慧品從微至著。若欲增 明甚相隨喜。且令西尼學語。更往中國請尼令足十數。(T.1804, p.51c10-18)

Afterwards eight Sinhalese bhikṣuṇis arrived (in China). They said: "There have not yet been bhikșuniss in the region of Song (= Liu Song dynasty, 420-479, in the south of China). How can one have obtained dual ordination?" Gunavarman said: "The bhikșunis have not followed the original rule. The rules were obtained $(=$ the ordination is valid), but an offense has been committed (by the monk teacher who administered the rules). ${ }^{55}$ [...] The (Chinese) nuns were anxious and asked to be ordained for a second time. He (Gunavarman) answered: "That is fine. Morality, meditation and wisdom progress from small to clear. If you want to increase the brightness (of the ordination), it will certainly give you joy. ${ }^{56}$ You must make the western bhikșun̄is study the language (= Chinese), and you must make more nuns come to China until the number of ten is reached."

This rather formal discussion is taken up again by the renowned vinaya master Dajue 大覺, who in the first half of the eighth century further explains and expands Daoxuan's commentary on the Dharmaguptakavinaya in his sub-commentary entitled Sifen lü xingshi chao pi 四分律行事鈔批, Comments on the Commentary on the Dharmaguptakavinaya (W Vol.67, p.217 to Vol.68, p.106). In this sub-commentary (W Vol.67, pp.604a9-606b8), Dajue further develops Daoxuan's account of the first Chinese nunneries. It is clear that he struggles with the validity of the Chinese nuns' ordination. He tries to argue that, even before the arrival of the Sinhalese nuns, ordinations for Chinese nuns had been taking place in a perfectly legal way, either because other foreign nuns had already transmitted the ordination tradition, or because Chinese ordinations were already based on an earlier genuine text and were carried out following Mahāprajāpatī’s example. The legal link with Śākyamuni Buddha

\footnotetext{
${ }^{54}$ See Ann Heirman, "Fifth Century Chinese Nuns: An Exemplary Case," Buddhist Studies Review, vol. 27 , no. 1 (2010): 65-66.

${ }^{55}$ Compare Biqiuni zhuan, T.2063, p.937b7-8: 又問就如律文戒師得罪何無異耶。'(The nun Huiguo) further asked (Gunavarman): "According to the vinaya texts, the teacher who administers the rules commits an offense. How can there be no difference (between our ordination and the ordination of Mahāprajāpatī)?"'

${ }^{56}$ This last sentence is parallel to Huijiao 慧皎, Gaoseng zhuan 高僧傳, Biographies of Eminent Monks, T.2059, p.341b4-5. Instead of the character 相 (xiang, each other), T.2059 has 助 (zhu, to help), which makes more sense: 'it will greatly help you to be joyful.'
} 
was thus always ensured. With the arrival of the Sinhalese nuns, Dajue says, a new start was taken, but without disavowing the earlier ordinations. ${ }^{57}$

In the above discussion, we can reveal yet another aspect of Daoxuan's viewpoints. Although it is clear that he prefers nuns to be hierarchically subordinate, he also wants to make sure that they have a legally recognized position in the Buddhist monastic institutions, continuing an unbroken line, starting from the first Buddhist nun, Mahāprajāpatī. This line, in fact, leads back to the Buddha's aunt and stepmother, a family tie, that, as we will see, is not to be underestimated neither in India nor in China.

\subsection{Filial piety}

Daoxuan finally highlights one more aspect related to women and their monastic role, and that is the multifaceted issue of filial piety, which equally includes the relation between the Buddha and his parents, especially his mother and stepmother. Filial piety is indeed an important issue in China, and so it comes as no surprise that Daoxuan pays attention to it. This does not imply, however, that filial piety was absent from the early Indian monastic context. As clearly shown by several studies of Gregory Schopen, Chinese Buddhists' focus on filial piety should certainly not be seen as a sign of 'sinicization' of Buddhism. ${ }^{58}$ On the contrary, Indian inscriptions clearly show how lay as well as monastic people frequently made religious gifts on behalf of their parents, living or dead, hoping to provide a source of merit for them. This being the case, the concept of filial piety remains particularly attractive to Chinese masters and lay people alike. One prominent example is the so-called Yulan pen 孟蘭盆 festival (Ullambana festival, or 'Ghost festival'), held at the end of the summer retreat, a festival that in medieval China attracted many people from all social classes who, aiming for the salvation of their ancestors, donated generous gifts to the Buddhist monastic community in exchange for transferable merit. ${ }^{59}$ As Stephen F. Teiser aptly expresses it, the Ghost festival allows monkhood to move 'into the very heart of family religion' ${ }^{60}$ Having left the family to

\footnotetext{
${ }^{57}$ On Dajue's arguments, see Heirman, "Fifth Century Chinese Nuns," 66-69.

${ }^{58}$ See, for instance, Gregory Schopen, 1997, "Filial Piety and the Monk in the Practice of Indian Buddhism, A Question of "Sinicization" Viewed from the Other Side," in Gregory Schopen, Bones, Stones, and Buddhist Monks, Collected Papers on the Archaeology, Epigraphy, and Texts of Monastic in India (Honolulu: University of Hawai'i Press, 2007; originally published in T'oung Pao, vol.70 (1984)) and "The Buddhist Bhikșu's Obligation to Support His Parents in Two Vinaya Traditions," The Journal of the Pali Text Society, vol. XXIX (2007): 112-132.

${ }^{59}$ On this festival, see, in particular, the meticulous study by Stephen F. Teiser, The Ghost Festival in Medieval China (Princeton: Princeton University Press, 1996 [1988]).

${ }^{60}$ Teiser, The Ghost Festival, 197.
} 
lead an ascetic life, monks are in a better position to serve their, and other people's, family members through the workings of karma. In addition, in the traditional account of the festival, a special dedication is shown to the mother, since she is the one who gave birth and who nurtured the children.

Daoxuan acknowledges the importance of filial piety and underlines how it is integrated in the story of Mahāprajāpatī. With a reference (T.1804, p.140c11-13) to the Dharmaguptakavinaya (T.1428, p.923a6-22), he relates how Ānanda asks the Buddha to allow Mahāprajāpatī to go forth on the ground that she nursed and raised him as a mother. ${ }^{61}$

四分阿難請授愛道戒中云。乳食長大有恩故。佛言。若聞三寶名字已是報恩。 (T.1804, p.140c11-13)

In the Dharmaguptakavinaya, Ānanda asks for the full ordination of Mahāprajāpatī: "She nursed and raised you. Therefore, you (should) show gratitude." The Buddha says: "Since she now hears the names of the Three Jewels, I have paid my debt of gratitude."

Daoxuan summarizes the Buddha's answer, and underlines what he considers to be the main aspects. He starts by highlighting how, thanks to the Buddha, Mahāprajāpatī can hear the names of the Three Jewels (Buddha, dharma, samgha), a most valuable repayment of the debt a son owes to his mother. The Buddha did even more and gave her the opportunity to become a (lay) believer. By focusing on the Buddha's answer, Daoxuan acknowledges that the debt the Buddha owes to his mother has been more than repaid. As we will see below, the textual tradition further emphasizes that the Buddha's love and respect for his mother remained unquestionable, but should not have forced him to abandon his opinion on the role of women. ${ }^{62}$

Daoxuan's arguments are part of a longer discussion on filial piety and debt to one's parents. He underlines that going forth does not mean that one leaves one's parents behind,

\footnotetext{
${ }^{61}$ In a brief remark in W Vol.64, p.72b12-16, Daoxuan equally links the Buddha's permission to ordain women to family ties between the Buddha and Mahāprajāpatī. When answering the question of why female monastic

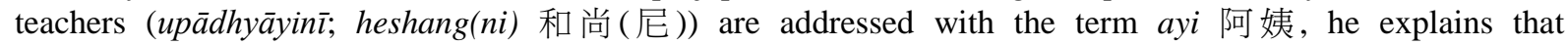
Mahāprajāpatī was in fact the Buddha's maternal aunt (yimu 姨母), which, according to him, explains the use of the character 姨. It also explains why women could go forth. ' $A$ ' (preceding 姨), he says, is an honorific title. In fact, the term 阿姨 is most probably a phonetic rendering of the Indian $\bar{a} r y \bar{a}$ ('honorable one'), and coincides with the term used in China to respectfully address, among others, one's aunt (cf. Ann Heirman, The Discipline in Four Parts, part II, p.297, note 135). In T.1804, p.152a15-16, in a discussion on the full ordination of nuns, Daoxuan again refers to the term ayi 阿姨. He explains that the use of this term refers to Mahāprajāpatī and that in this way the tradition (of ordinations) remains unbroken.

${ }^{62}$ For a detailed study on the Buddha's debt to his (step-)mother, see Reiko Ohnuma, "Debt to the Mother: A Neglected Aspect of the Founding of the Buddhist Nuns' Order," Journal of the American Academy of Religion, vol. 74, note 4 (2006).
} 
but, instead, he says, it is a way to repay one's debt. In this discussion, Daoxuan refers a second time (T.1804, p.140c26-27) to Mahāprajāpatī, this time relying on the Zeng yi ahan jing 增壹阿含經, Ekottarāgama (T.125, p.823a21-22), translated into Chinese at the end of the fourth century ${ }^{63}$ : when his stepmother passed away, the Buddha personally helped to lift her deathbed. Daoxuan further adds (p.140c27-28) that, when the Buddha's father Śuddhodana passed away, the Buddha also transported his corpse. ${ }^{64}$ These remarks again focus on the continuous respect paid to their parents by Buddhist monastics, despite their having left home. From these remarks, one can also see that Daoxuan is quite concerned to ascertain that a monastic life does not in any way undermine the respect one owes to one's parents, both mother and father. ${ }^{65}$

Two encyclopedic commentaries by Daoxuan's fellow monk Daoshi 道世 (?-683), the Fayuan zhulin 法苑珠林, Forest of Gems in the Garden of Law (T.2122), and the largely parallel commentary, the Zhujing yaoji 諸經 要 集, Collection of the Essentials of the Sütras (T.2123), further refine Daoxuan's arguments. Scattered over the commentaries, we find several stories and opinions on filial piety, in relation to the Buddha and Mahāprajāpatī. In T.2122, p.606b24-c16 and T.2123, p.40a25-b17, we learn that the Buddha is fully accomplished and does not, and cannot, acquire additional merit. Still, he pays homage to his deceased (step)mother, and burns incense as a sign of gratitude. Although he

\footnotetext{
${ }^{63}$ The affiliation of this text is not yet established (see, among others, Fumio Enomoto, "On the Formation of the Original Texts of the Chinese Āgamas," Buddhist Studies Review, vol. 3, no. 1 (1986): 25; Akira Hirakawa, translated and edited by Paul Groner, A History of Indian Buddhism, From Śākyamuni to Early Mahāyāna (Honolulu: University of Hawai'i Press, 1990), 73), although some argue for a Dharmaguptaka, Mahāsāṃghika or a Sarvāstivāda connection (for references, see, among others, Anthony Kennedy Warder, Indian Buddhism (Delhi: Motilal Banarsidass, 1970 [1991]): 8-9; Egaku Mayeda, "Japanese Studies on the Schools of the Chinese Āgamas," in Heinz Bechert (ed.), Zur Schulzugehörigkeit von Werken der Hinnayāna-Literatur, Erster Teil (Göttingen: Vandenhoeck \& Ruprecht, 1985), 102-103; Thomas Oberlies, "Ein bibliographischer Überblick über die kanonischen Texte der Śrāvakayāna-Schulen des Buddhismus (ausgenommen der des MahāvihāraTheravāda)," Wiener Zeitschrift für die Kunde Südasiens, vol. 47 (2003): 72).

${ }^{64}$ How the Buddha paid respect to his deceased father is related in detail in the Jingfan wang banniepan jing 淨 飯王般涅槃經, Śuddhodanarājaparinirvānasūtra (T.512), translated into Chinese in the fifth century.

${ }^{65}$ On filial piety in Chinese Buddhism, see Kenneth K. S. Ch'en, "Filial piety in Chinese Buddhism," Harvard Journal of Asiatic Studies vol. 28 (1968): 81-97, who in his pioneering article underlines its importance in Chinese society. Partly in response to Ch'en, many others have analyzed filial piety in a Buddhist context, often showing how the concept was equally important in Indian Buddhism, while acquiring a particular status in the Confucian environment of China. For an overview, see Guang Xing, "Filial Piety in Early Buddhism," Journal of Buddhist Ethics, vol. 12 (2005): 82-106, who equally points out several similarities between Indian and Chinese Buddhism on the concept of filial piety. See also Alan Cole, Mothers and Sons in Chinese Buddhism (Stanford: Stanford University Press, 1998), 41-55, who analyzes how Indian aspects were made relevant to Chinese concerns.
} 
does not need to do so, he wants to set an example to others, showing them how they can acquire merit by honoring their parents. ${ }^{66}$

佛報言。我雖功德已滿。我深知功德恩報力故。令我於一切眾生中得最第一。 由此功德又為欲教化弟子故語之言。我尚作功德。汝云何不作。如伎家百歲老 翁而舞。有人訶之言。老翁年已百歲。何用是舞。老翁答曰。我不須舞但欲教 子孫故耳。佛亦如是。功德雖滿。為教弟子作功德。故而作供養。故佛乳母大 愛道亡。四天王輿床送。佛在前擎香鑪燒香供養。為報恩故。雖不求果而行等 供養。(T.2122, p.606c4-13)

The Buddha stated: "Although my merit is fully accomplished, I deeply understand the power of merit and gratitude. Therefore, I obtained the first place among all living beings. Because of this merit, I want to admonish my disciples. Therefore I tell them: 'I still do (acts of) merit. Why do you not do it? It is like of family of performers where an old man of one hundred years still dances. There are people who criticize him: 'Old man, you are already one hundred years old. You still dance. What is the need?' The old man answered: 'I do not need to dance. I only want to teach my sons and grandsons.' The Buddha is also like this. Although his merit is accomplished, he still wants to teach his disciples to do (acts of) merit. Therefore he (also) pays homage. Therefore, when the Buddha's foster mother, Mahāprajāpatī, passed away, he escorted her deathbed with the four heavenly kings (= the four guardian gods who protect the four quarters of the universe). In the front, he held up perfume and incense sticks and paid homage. Because of the debt of gratitude, although he does not obtain any result (merit), he performs all the (acts of ) paying homage."”

Furthermore, in a summary (T.2122, pp.999c28-1000a14 and T.2123, p.179b14-29) of the Fomu bannihuan jing 佛母般泥洹經 (Mahäparinirvānasūtra of the Buddha's Mother, T.145), the translation of which is attributed to a monk called Huijian 慧簡 (5th century) ${ }^{67}$, we are told how Mahāprajāpatī wants to pass away before the decease of her (step)son, the Buddha. She goes to see him together with 500 women nuns. Her wish is accomplished: she and the 500 women all reach parinirvanga at the same time, the Buddha still being alive. The women are consequently honored and cremated with all due respect. Mahāprajāpatī's relics are brought to the Buddha, who states that his mother has been freed from her dirty (female) body full of bad feelings, and is now able to act as a man, which will bring her to arhat-ship. ${ }^{68}$ Finally, a temple is built in honor of her and her female disciples.

\footnotetext{
${ }^{66}$ Daoshi's arguments, in fact, rely fully on some discussions recorded in the Da zhidu lun 大智度論, Mahāprajñāpāramitā Śāstra (T.1509, pp.128c25-129a21, and p.132a6-17).

${ }^{67} \mathrm{Cf}$. Demiéville et al., Répertoire du canon bouddhique sino-japonais, 27 and 245.

${ }^{68}$ T.2122, p.1000a12-14; T.2123, p.179b27-29; T.145, p.870b17-21.
} 
告諸比丘。斯聚舍利本是穢身。兇愚急暴。廮妒陰謀。敗道壞德。今母能拔興 丈夫行。獲應真道。 $[\ldots$. 敕令興廟供養。(T.2122, p.1000a12-14)

He (the Buddha) told the bhikṣus: "These relics (of Mahāprajāpatī and her female disciples) originally were dirty bodies, fearful, foolish, anxious and violent, full of jealousy and conspiracy, losing the path and harboring bad feelings. My mother can now get rid of this and be promoted to the actions of a man. She can obtain the true path. [...] He then ordered to build a temple and to pay homage.

Referring (T.2122, p.1000a15-28 and T.2123, p.179c1-14) to the Zeng yi ahan jing (T.125, pp.822b29-823b17), Daoshi further relates how the Buddha praises the practice of respectfully taking care of the funeral of one's parents, honoring them, just as former Buddhas had done before him. And indeed, the Buddha personally lifts Mahāprajāpatī’s deathbed, puts wood on her pyre, and states that a stüpa should be erected in her honor. A short, but interesting, concluding remark further states that Mahāprajāpatī is not only the stepmother (of the Buddha), but is also a biological mother, namely of Nanda, a monk who assists ${ }^{69}$ the Buddha with Mahāprajāpatı̂’s funeral (T.2122, p.1000a28-29 and T.2123, p.179c15).$^{70}$ In this sense, Mahāprajāpatî̀'s status as a mother is intensified, just like the filial piety shown to her.

\begin{abstract}
又增一阿含經云。佛告阿難陀羅雲。汝等輿大愛道身。我當親自供養。爾時釋 提桓因四天王等。前白佛言。唯願勿自勞神。我等自當供養。佛言。止止。所 以然者。父母生子多有所益。長養恩重乳哺懷抱。要當報恩不得不報。過去未 來諸佛母。先取滅度。諸佛皆自供養闍維舍利也。時毘沙門天王使諸鬼神往梅 檀林取梅檀薪。至曠野之間。佛躬自舉床一腳。阿難舆一腳。飛在虛空。往至 塚間。爾時佛自取梅檀木著大愛道身上。佛言。有四人應起塔供養。一者佛。 二者辟支佛。三者漏盡阿羅漢。四者轉輪聖王。皆以十善化物故。爾時人民即 取舍利。各起塔供養。依雜阿含經。愛道姨母。即是難陀親母也。(T.2122, p.1000a15-29)
\end{abstract}

Further, the Zeng yi ahan jing says: "The Buddha told Ānanda and Rāhula: 'You should carry the body of Mahāprajāpatī. I shall personally pay homage.' Then, Sākradevendra, the four heavenly kings and others came forward and said to the Buddha: 'We only want to say: 'Do not bother yourself with it. We shall pay homage ourselves.' The Buddha said ${ }^{71}$ : 'Wait, wait. Why so? When parents have children there is a lot of benefice. They raise them, they show kindness, they nourish them and they cherish them. One owes them a debt of gratitude. One cannot not pay one's debt of

\footnotetext{
${ }^{69}$ As mentioned in the Zeng yi ahan jing, T.125, p.823a21.

${ }^{70}$ Daoshi hereby refers to the Za ahan jing 雜阿含經, Samyuktāgama (usually attributed to the (Mūla)Sarvāstivāda tradition, and translated into Chinese in the middle of fifth century), T.99, p.277a11, where the monk Nanda is indeed presented as the biological son of the Buddha's stepmother. On the Za ahan jing's school attribution, see Warder, Indian Buddhism, 8; Mayeda, "Japanese Studies on the Schools," 99; Enomoto, "On the Formation of the Original Texts," 23; Hirakawa, A History of Indian Buddhism, 71.

${ }^{71}$ In the Zeng yi ahan jing (T.125, p.823a9- ), it is in fact the Buddha's disciple Śăriputra who says this.
} 
gratitude. When the mothers of the past and of the future Buddhas pass away, the Buddhas all pay homage themselves and set fire (shewei 闍維, causative of the Skt. kșāyati, to burn) to the body.' Then the sramanas of Vaissāli and the heavenly kings made the ghosts go to a sandalwood forest to take sandalwood firewood. They arrived at an open space. The Buddha personally lifted one foot of the (death)bed. Ananda (also) took one foot. They flew into the air and arrived at the cemetery. Then the Buddha personally took the sandalwood and put it on top of Mahāprajāpatī's body. The Buddha said: 'Only for four people can one make a stüpa to pay homage. These are, one, a Buddha; two, a Pratyekabuddha; three, an Arhat who has eliminated all contamination; four, a Wheel-Turning King. This is all because of the ten virtues.' Then, the people took the relics (sarìra) and they all made a stüpa to pay homage." As the Za ahan jing says: "Mahāprajāpatî is (the Buddha's) maternal aunt (and thus also stepmother). She is the biological mother of Nanda."

Despite the respect shown to Mahāprajāpatī, Daoshi equally warns of the potentially bad effects of the full ordination of the first nuns. With a reference (T.2122, p.1006c18-26) to the Shanjian lü piposha 善見律毘婆沙 (T.1462, pp.796c20-797a1), the Chinese version of the Pāli vinaya commentary, the Samantapāsādikāa, Daoshi states that, due to the acceptance of women into the Buddhist monastic community, there was the risk that the dharma would only last for 500 years, instead of $1000 .^{72}$ The Buddha could ward off this danger by imposing the eight important rules. ${ }^{73}$ After 1000 years, the dharma is predicted to slowly decline. Just like Daoxuan, Daoshi (pp.1006c27-1007b3) also refers to the blaming of Ānanda by the monk Kāśyapa, as recorded in the Pinimu jing, showing how he disapproves of Ānanda's intervention on behalf of Mahāprajāpatî.

The above accounts of women and mothers contain multiple aspects: a woman, even one's mother, has more bad feelings than a man. Nevertheless, a mother (just like a father) must be honored; an act that also brings merit to the children. This does not mean, however, that the debt owed to the mother should have been used as an argument for allowing women to enter

\footnotetext{
${ }^{72}$ The same passage is also referred to by Huaisu in his Sifen lü kaizong ji, W Vol.67, pp.164b15-165a3. For a translation, see Purushottam Vishvanath Bapat and Akira Hirakawa, 善見毘婆沙 Shan-Chien-P'i-P'o-Sha, A Chinese version by Sanghabhadra of Samantapāsādikā (Poona: Bhandarkar Oriental Research Institute, 1970), 534-535.

The Samantapāsādikā is traditionally attributed to the monk Buddhaghosa (on this attribution and the doubts it raises, see Oskar von Hinüber, A Handbook of Pāli Literature (Berlin: Walter de Gruyter, 1996), 103-104). The Chinese Shanjian lü piposha (T.1462) is often seen as a translation (completed in 488-489) of the Samantapāsādikā, attributed to the monk Samghabhadra. Its relation to the Pâli text, however, is not that straightforward, and has been the topic of many debates. For details on this text, and a discussion on its relationship to the Pāli Samantapāsādikā, see a recent study by Gudrun Pinte, Lost in Translation: A Case Study of Sanghabhadra's Shanjian lü piposha, Ph.D. Ghent University, 2011.

${ }^{73}$ Daoshi (T.2122, p.563a13-28) also tells his readers how the Buddha, after his passing away, calls all monks to the Sumeru mountain, and warns them of the dangers for the Buddhist law. One of these dangers are wicked nuns who do not abide by the eight important rules.
} 
the Buddhist community as fully ordained nuns. By making it possible for his stepmother to hear about the Three Jewels and to become a lay believer, the Buddha had already repaid his due debt. One should not have asked for more. This reasoning integrates two major points: going forth is an act of filial piety, but it might have been better for women to remain lay believers. However, the Buddha finally admitted women (being forced into it by Ānanda) and imposed the eight important rules. They should not be trespassed, and so naturally insure an institutionally higher position for monks.

\section{Conclusion}

Despite the fact that Buddhist nuns have acquired their place in monasteries, as shown in biographies, memorials, manuscripts, and inscriptions alike, Tang vinaya masters hold on to quite a strict discourse on the women's role and position in Buddhist institutions, and do not allocate them much responsibility. However, women can act as teachers and are seen as full members of the monastic community, be it in a subordinate position. This opinion is not that surprising given the masters' reliance on the basic vinaya texts that generally hold the same position. In the vinaya masters' disciplinary commentaries on women, we see neither an idealization of certain kinds of female practices nor an outspoken demonization of women as seductive and untrustworthy, as is common in other texts. Instead, the focus lies on subordination.

The most productive master was undoubtedly Daoxuan. Other vinaya masters say much less, but if they do, they display very similar viewpoints. Of the many issues on nuns raised by all kinds of vinaya texts, Daoxuan selects what he probably saw as the most important aspects, or at least those elements he thought of being important to point out in a commentary. He makes sure he carefully quotes the sources he sees as authoritative. In this way he never or very rarely says anything for which he cannot find a reference. He does not express his ideas in his own words, but rather he constructs them on the basis of a selection of older, authoritative passages. This methodology strengthens his arguments, even if his selection is personal. The passages he highlights, however, are not only pointed out by him. Other masters, although they have less to say on the position of nuns, refer to some of the same passages, showing that the positions taken by Daoxuan remain, as far as we can see from the extant commentaries, unchallenged, and are agreed upon rather commonly among Tang vinaya masters.

In his discussion on nuns, Daoxuan refers both to the loss of respect and revenue that Buddhist monks are said to have suffered when women were admitted into the order, and to 
the monk Kāśyapa's critique on Ānanda. It clearly shows that Daoxuan himself takes a rather negative view on what happened when the Buddha allowed women to become nuns. He underlines that there was even the risk of the Buddhist dharma lasting half as long, a fate which could be prevented by the Buddha only by imposing eight important rules (gurudharma) on Mahāprajāpatī and all other future Buddhist nuns. Since these rules function as a buffer against moral deprivation, safeguarding the dharma, they obviously need to be strictly adhered to. Daoxuan further explains why women inevitably find themselves in this position: women are confused, they do not want to learn and only know about small things. This passage is also popular among other masters, and shows how women, apart from being institutionally subordinate, are also seen as emotionally and intellectually weaker.

Still, Daoxuan also has fully accepted the nuns' presence in the Buddhist order, which is only logical, given the fact that the Buddha allowed them to be there. And, although he wants nuns to be hierarchically subordinate, he also strives to ascertain that they have a legally recognized position, in an unbroken ordination line going back to the first Buddhist nun, Mahāprajāpatī, the Buddha's aunt and stepmother. This family tie brings along the theme of filial piety. And indeed, the fourth and final point addressed by Daoxuan with regard to nuns is the care for one's parents, and particularly for the mother. Honoring one's parents also gives merit to oneself, but, more importantly, by being a monastic, and with the help of ceremonies, merit can also be transferred to one's deceased family members. In this way, one repays the debt one owes to parents. Daoxuan adds that women, even one's mother, have more bad feelings than men. Nevertheless, a mother (as well as a father) must be properly honored, just as the Buddha did for Mahāprajāpatī, even saving her from womankind.

In summary, the standard and authoritative story displayed by Daoxuan tells us that, while nuns have once put the dharma at risk when they entered the monastic order, they are now legally recognized, but still in need of guidance, unable to control themselves. ${ }^{74}$ Furthermore, the danger (of women) has not completely disappeared, so the gurudharmas must firmly remain in place. Still, even in such a position, women also honor their parents by going forth, which legitimizes their monastic role. This is an institutional viewpoint, corroborated through the use of carefully selected passages from many authoritative texts. As such, the standard vinaya story attributes to women a place in the Buddhist order, well under the control of their male colleagues, a status which - according to the Tang vinaya masters -

\footnotetext{
${ }^{74}$ On this unability of self-control, see also Wendi Adamek, “A Niche of Their Own,” 20.
} 
due to women's emotional and intellectual weakness and the danger they continue to impersonate, is not open to change. 


\section{Abbreviations}

T Taishō shinshū daizōkyō 大正新修大蔵經. 85 vols., eds. Takakusu Junjirō 高楠順 次郎 and Watanabe Kaigyoku 渡邊海旭. Tokyo: Taishō Issaikyō Kankōkai, 192434.

W Wan xuzang jing 记續藏經. 150 vols., ed. Xinwenfeng Bianshenbu 新文豐編審部. Taipei: Xinwenfeng Chuban.

\section{Bibliography Chinese works}

Ciyi 慈怡, 《佛光大辭典》. (高雄: 佛光出版社, 1988) (重印本). 北京: 北京圖書館出版社, 1989.

Hao Chunwen 郝春文, 《唐后期五代宋初敦惶僧尼的社会生活》. 北京: 北京中国社会科学 出版社, 1998.

Li Yuzhen 李玉珍,《唐代的比丘尼》. 臺北: 台灣學生書局, 1989.

Tang Yongtong 湯用粀, “論中国佛教无 “十宗”.”《哲学研究》,第 3 (1962 年), 第 47-54 頁.

Tang Yongtong 湯用拥, “中国佛教宗派問題补論.” 《北京大学学報》, 第 5 (1963 年), 第 118 頁.

Tang Yongtong 湯用泮, 《漢魏兩晉南北朝 佛教史》. (長沙: 商務印書館, 1938) (重印 本). 板橋: 駱駝出版社, 1996.

Wang Jianguang 王建光，《中国律宗通史》. 南京: 凤凰出版社, 2008.

Yao Ping 姚平, 《唐妇女的生命历程》. 上海: 上海古籍出版社, 2004. 